\title{
ВЛИЯНИЕ КОНЪЮНКТУРЫ РЫНКА ТРУДА НА ЭКОНОМИЧЕСКУЮ БЕЗОПАСНОСТЬ РЕСПУБЛИКИ МОЛДОВА 1
}

\author{
Галина САВЕЛЬЕВАС ${ }^{2}$, кандидат экономических наук, доцент, \\ Светлана 3АХAPOB ${ }^{3}{ }^{3}$, кандидат экономических наук, \\ Центр Демографических исследований, \\ Национальный Институт Экономических Исследований, \\ Республика Молдова
}

DOI: https://doi.org/10.36004/nier.cdr.2021.15-11

\begin{abstract}
Piața muncii este unul dintre principalii factori ai securității economice. Scopul studiului constă în analiza particularitățile piețelor muncii regionale pe baza unei evaluări a schimbărilor conjuncturii, a impactului acestora asupra securității economice și a echilibrului pieței naționale a muncii. Diagnosticul modificărilor în principalii indicatori statistici și a celor calculați (secundari) ai pieței muncii în dinamică s-a efectuat pe baza metodelor de analiză și sinteză, grafice, de calcule proprii de către autorii unor indicatori specifici. Pe baza rezultatelor obținute s-au elaborat concluzii cu privire la dezvoltarea piețelor regionale de muncă, prezența amenințărilor la adresa securității economice, precum și măsuri pentru îmbunătățirea acestei situații în Republica Moldova.
\end{abstract}

Cuvinte cheie: șomaj, ocupare, venituri, migrație, riscuri sociale, piața muncii, populație aptă de muncă, securitate economică.

Abstract. The labour market is one of the main factors of economic security. The purpose of the research is to analyze the features of regional labour markets based on an estimation of market changes, their impact on economic security and the balance of the national labour market. Diagnostics of changes in the main statistical and calculated (secondary) indicators of labour market in dynamics is carried out on the basis of methods of analysis and synthesis, graphical, calculations by the authors of specific indicators. Based on the results obtained, conclusions were drawn about the development of regional labour markets, the presence of threats to economic security, as well as measures to improve this situation in the Republic of Moldova.

Key words: unemployment, employment, wages, migration, social risks, labour market, working age population, economic security.

JEL Classification: E24, J21; J31; J62.

Введение, научные теории. В условиях нестабильности социальноэкономического развития Республики Молдова актуальность экономической безопасности возрастает, что вызывает необходимость выявления факторов ограничительного или негативного воздействия на развитие страны и разработки политик по усилению ее экономической безопасности, в том числе территориальной. Понятие

\footnotetext{
1 Статья разработана в процессе выполнения Государственной Программы (20202023) 20.80009.0807.21 Migrația, schimbări demografice și politici de stabilizare a situației / Миграция, демографические изменения и политики по стабилизации ситуации.

2 Галина Савельева, gts6@mai.ru.

3 Светлана Захаров, zaharov.svetlana@gmail.com.
} 
экономической безопасности не является новым оно используется как европейскими, так и американскими экономистами (Cable, 1995) (Freeman, 1995), отражены в трудах российских ученых Л.И. Абалкина, В.К. Сенчагова, С.Ю. Глазьева, А.И. Илларионова, И.Я. Богданова и других. Л.И.Абалкин (Абалкин, 1994) под экономической безопасностью подразумевает «совокупность условий и факторов, обеспечивающих независимость национальной экономики, ее стабильность и устойчивость, способность к постоянному обновлению и самосовершенствованию», она зависит от структурной перестройки экономики, инновационного и инвестиционного развития, качества человеческого капитала и других факторов. В научных работах приводятся различные факторы рисков и показатели оценки экономической безопасности, характеризующие разные социальноэкономические сферы (например, Центр финансово-банковских исследований ИЭ РАН использует для оценки 150 показателей (Гладун). Экономическую безопасность рассматривается как единая система и как совокупность условий и факторов, обеспечивающих стабильность, устойчивость, способность к постоянному развитию, конкурентоспособность экономики, в том числе наличие механизма защиты и противодействия внешним и внутренним угрозам. При этом условием является наличие квалифицированных кадров, занятость и сбалансированный рынок рабочей силы. Для оценки угроз рынка труда используются показатели сокращения численности трудоспособного населения, доля экономически активного населения в общей численности населения трудоспособного возраста, уровни занятости и безработицы, трудовая миграция, напряженность на рынке труда, неформальная занятость, качество рабочей силы, доходы, бедность (Зайцева, 2021).

Республика Молдова, в силу неопределенности и непредсказуемости тенденций социально-экономического развития сталкивается с рядом проблем, в том числе с ограниченностью ресурсов рабочей силы, что может иметь последствия на ближайшее будущее, если не будет изменена парадигма развития, в том числе адаптация рынка труда к IT- технологиям, формированию рыночных общественных отношений, повышению профессионального мастерства и уровня образования в условиях процессов глобализации. Все это подразумевает наличие человеческого капитала и его качественное образование на протяжении всей жизни, создание безопасных для здоровья условий труда, устойчивость доходов, смягчение социального неравенства, сокращение неформальной занятости, совершенствование механизмов социальной и правовой защиты. На экономику влияют также глобальные процессы в связи с ужесточением конкуренции на региональных товарных рынках, нестабильностью цен на нефть на 
мировом рынке, новым вызовом, начиная с 2020г., кризисом пандемии Covid-19. Как следствие этих процессов, мониторинг и своевременное реагирование являются необходимым условием обеспечения устойчивого экономического развития, в том числе рынка труда как основной его составляющей и, особенно, социально-значимым показателям о занятости и безработице, как некоторой характеристики национального благополучия, эффективности экономических реформ и стабильности экономического развития.

Методология, методы исследования. Для анализа влияния рынка труда на экономическую безопасность использованы комплексный и системный подходы и методы сравнительного анализа, графический, статистический, логический, аналогий. Исследование исходит из понятия «конъюнктура рынка труда», как реальной ситуации в результате спроса и предложения труда, воздействия на рынок государства и других взаимосвязанных с ним институтов и проявляется в 3-х состояниях: сбалансированное (при равновесии спроса и предложения на труд), трудодефицитное (спрос на труд превышает предложение) и трудоизбыточное (предложение на труд превышает спрос и появление безработицы), два последних состояния являются угрозами экономической безопасности как для региона, так и для страны в целом, безработица является риском для получения доходов, изменения качественного и количественного потенциала трудовых ресурсов.

Для оценки рынка труда использованы официальные статистические показатели уровня участия населения в экономической деятельности, занятости, безработица (по методологии МБТ), данные Национального Агентства по Занятости Населения (НАЗН) о численности зарегистрированных безработных и наличии вакантных рабочих мест. Такой подход позволил оценить реальный спрос на рабочую силу, ее качественные характеристики (профессионализм, уровень образования и т.д.). Своеобразным индикатором спроса и предложения является коэффициент напряженности на рынке труда (отношение численности зарегистрированных безработных к количеству вакантных рабочих мест), но он не может быть всеобъемлющим, так как помимо государственных служб занятости трудоустройством населения занимаются частные агентства занятости и полная информация в данной области отсутствует. Однако для анализа конъюнктурных особенностей национального и региональных рынков труда и определения возможных угроз вышеназванные показатели могут быть использованы.

Результаты исследования. Предложение рабочей силы, в первую очередь, определяется демографическими факторами. В Республике Молдова основной тенденцией стало сокращение численности 
населения и процесс его старения (по данным НБС численность населения на 01.01.2021г. сократилась на 46,8 тыс.чел. по сравнению с 01.01.2020г., как результат отрицательного естественного прироста и миграционной убыли). На рынок труда влияет фактор глобализации, который с одной стороны, способствует повышению активности экономических агентов, а с другой стороны, открытость пространства и свободное перемещение повышает мобильность, а усиление миграционных процессов и отток рабочей силы, в основном, молодежи и квалифицированных работников ведет к диспропорциям на рынке труда, депопуляции, изменению структуры рабочей силы и ее качества, что становится фактором риска безопасности экономического развития. Показатели участия населения в экономической деятельности отражены в Таблице 1.

Таблица 1. Характеристика трудоспособного населения по участию в экономической деятельности в Республике Молдова

\begin{tabular}{|c|c|c|c|c|c|}
\hline $\begin{array}{c}\text { Наименование показателей, } \\
\text { территориальных единиц }\end{array}$ & 2016 & 2017 & 2018 & 2019* & 2020* \\
\hline $\begin{array}{l}\text { Население в трудоспособном возрасте, } \\
\text { всего }\end{array}$ & 2313,2 & 2267,3 & 2220,2 & 2175,2 & 2150,9 \\
\hline $\begin{array}{l}\text { Экономически активное население, } \\
\text { тыс.чел. }\end{array}$ & 1035,3 & 999,7 & 1018,1 & 919,3 & 867,3 \\
\hline \multicolumn{6}{|c|}{ в \% от экономически активного населения по стране по муниципию и регионам: } \\
\hline Мун.Кишинэу & 26,9 & 26,7 & 25,5 & 30,4 & 29,8 \\
\hline Север & 29,3 & 29,6 & 29,5 & 29,6 & 30,1 \\
\hline Центр & 28,3 & 27,8 & 29,3 & 25,3 & 25,6 \\
\hline Юг & 15,5 & 15,9 & 15,7 & 14,7 & 14,5 \\
\hline $\begin{array}{l}\text { Экономически неактивное население, } \\
\text { тыс.чел. }\end{array}$ & 1277,9 & 1267,6 & 1202,1 & 1255,9 & 1283,6 \\
\hline \multicolumn{6}{|c|}{ в \% от экономически неактивного населения по стране по муниципию и регионам: } \\
\hline Мун.Кишинэу & 21,7 & 21,9 & 21,8 & 18,1 & 19,2 \\
\hline Север & 26,6 & 26,3 & 26,8 & 27,1 & 27,0 \\
\hline Центр & 30,4 & 30,9 & 30,2 & 33,1 & 32,4 \\
\hline Юг & 21,3 & 20,9 & 21,2 & 21,7 & 21,4 \\
\hline \multicolumn{6}{|c|}{$\begin{array}{c}\text { Доля экономически неактивного населения в трудоспособном населении, } 15 \text { лет и } \\
\text { более, \% }\end{array}$} \\
\hline Республика Молдова & 55,3 & 55,9 & 54,1 & 57,7 & 59,7 \\
\hline Мун.Кишинэу & 49,8 & 51,0 & 50,2 & 44,9 & 48,8 \\
\hline Север & 52,8 & 52,9 & 51,7 & 55,6 & 57,0 \\
\hline Центр & 57,0 & 58,4 & 54,9 & 64,1 & 65,2 \\
\hline Юг & 63,1 & 62,7 & 61,6 & 66,8 & 68,6 \\
\hline
\end{tabular}

*Примечание: 2019-2020г.г. несравнимы с предыдущим периодом в связи с изменением методологии обследования в соответствии со стандартами ЕС.

Источник: Расчеты авторов на основе статистических данных НБС РМ, https://statbank.statistica.md/pxweb/pxweb/ro/30\%20Statistica\%20sociala/30\%20Statis tica\%20sociala_03\%20FM_03\%20MUN2019_MUN080/?rxid=b2ff27d7-0b96-43c9-934b42e1a2a9a774 
При анализе данных о населении в трудоспособном возрасте прослеживается тенденция уменьшения: за 2016-2018г.г. численность трудоспособного населения сократилось на 4,0\%, а за 2020г. на 1,1\% по сравнению с 2019г. Аналогичная ситуация имеет место при оценке экономически активного населения: в 2018г. сокращение на 1,7\% по сравнению с 2016г. и на 5,7\% в 2020г. по сравнению с 2019г. Основную долю в экономически активном населении составляет Северная зона $(30,1 \%)$ и мун.Кишинэу $(29,8 \%)$ или практически $60 \%$, а остальные $40 \%$ приходятся на Центральную и Южную зоны, удельный вес которых имел тенденцию к уменьшению из-за влияния как факторов социальноэкономического характера, так и демографических.

Отрицательным фактором для формирования рынка труда является рост и преобладающая доля экономически неактивного населения в общей численности трудоспособного населения, которая в 2019-2020г.г. практически достигла уровня 60\%, в том числе в Центральной и Южной зонах даже превысила уровень $65 \%$. Значительная его доля (вплоть до 90\%) это население, которое не ищет и не расположено работать, то есть сложно рассчитывать на потенциал или резерв для воспроизводства рынка рабочей силы или покрытия его дефицита. Доля пенсионеров по возрасту в экономически неактивном населении в 2019-2020г.г. составляла 45\%, однако часть данной категории, 24\% в среднем по стране и от $19 \%$ до 24\% по регионам, заняты на рынке труда (Таблица 2). Занятость для пенсионеров является дополнительным средством дохода и стимулом улучшения материального благосостояния, а для работодателей - выгодным дополнительным ресурсом рабочей силы, без особых претензий на какие-то льготные условия в силу своего социального статуса «пенсионер».

Таблица 2. Структура экономически неактивного населения по отношению к рынку труда

\begin{tabular}{|l|c|c|c|c|c|}
\hline & $\mathbf{2 0 1 6}$ & $\mathbf{2 0 1 7}$ & $\mathbf{2 0 1 8}$ & $\mathbf{2 0 1 9}$ & $\mathbf{2 0 2 0}$ \\
\hline $\begin{array}{l}\text { Всего население, которое не ищет и } \\
\text { недоступно для работы, тыс. человек. } \\
\text { В том числе \% от общего количества в: }\end{array}$ & 1122,6 & 1108,4 & 1039,7 & 1126,3 & 1177,9 \\
\hline Мун.Кишинэу & 23,5 & 23,6 & 23,8 & 19,2 & 19,8 \\
\hline Север & 26,0 & 26,7 & 27,0 & 27,2 & 27,0 \\
\hline Центр & 30,2 & 29,6 & 29,0 & 32,3 & 31,9 \\
\hline Юг & 20,3 & 20,1 & 20,2 & 21,3 & 21,3 \\
\hline $\begin{array}{l}\text { Экономически неактивное население } \\
\text { по РМ, \% } \\
\text { в том числе: }\end{array}$ & 100,0 & 100,0 & 100,0 & 100,0 & 100,0 \\
\hline -в поиске работы, но не готово работать & 0,1 & 0,1 & 0,1 & 0,2 & 0,1 \\
\hline -не ищет, но доступно для работы & 1,1 & 0,7 & 0,5 & 1,2 & 0,7 \\
\hline -хочет работать, но не ищет & 0,9 & 0,7 & 0,6 & 0,5 & 0,4 \\
\hline -не ищет и недоступно для работы & 87,8 & 87,4 & 86,5 & 89,7 & 91,8 \\
\hline
\end{tabular}




\begin{tabular}{|l|c|c|c|c|c|}
\hline -уехавшие на работу за пределы страны & 10,1 & 11,1 & 12,3 & 8,4 & 7,0 \\
\hline $\begin{array}{l}\text { Доля пенсионеров в населении, } \\
\text { которое не ищет и недоступно для } \\
\text { работы, \%, по РМ, в том числе в: }\end{array}$ & 47,6 & 47,6 & 48,6 & 50,3 & 49,2 \\
\hline Мун.Кишинэу, \% & 54,4 & 54,4 & 53,1 & 49,1 & 47,4 \\
\hline Север, \% & 47,8 & 45,5 & 47,5 & 52,3 & 52,3 \\
\hline Центр, \% & 43,2 & 44,6 & 46,4 & 49,6 & 48,4 \\
\hline Юг, \% & 46,1 & 46,4 & 47,5 & 49,7 & 48,3 \\
\hline $\begin{array}{l}\text { Доля пенсионеров по возрасту, занятых } \\
\text { на рынке труда, в \% к общей } \\
\text { численности пенсионеров по РМ, в том } \\
\text { числе в: }\end{array}$ & 23,3 & 23,3 & 23,0 & 23,4 & 23,7 \\
\hline мун.Кишинэу & 37,2 & 36,8 & 36,1 & 36,1 & 35,6 \\
\hline Север & 19,2 & 19,1 & 18,9 & 19,2 & 19,6 \\
\hline Центр & 19,5 & 19,6 & 19,2 & 20,0 & 20,6 \\
\hline Юг & 19,1 & 19,0 & 18,6 & 18,8 & 19,4 \\
\hline АТО Гагаузия & 22,1 & 22,7 & 23,2 & 23,5 & 23,9 \\
\hline
\end{tabular}

*Примечание: 2019-2020г.г. несравнимы с предыдущими годами, Исследование рабочей силы в домашних хозяйствах (Анкета обследования рабочей силы) проведено согласно новому плану исследования и понятию занятой рабочей силы.

Источник: Расчеты авторов на основе статистических данных НБС РМ, www.statistica.md,

https://statbank.statistica.md/pxweb/pxweb/ro/30\%20Statistica\%20sociala/30\%20Statis tica\%20sociala_03\%20FM_03\%20MUN2019_MUN080/?rxid=b2ff27d7-0b96-43c9-934b42e1a2a9a774

В структуре экономически неактивного населения основную долю (в 2019-2020г.г., соответственно, 89,7\% и 91,8\%) составляет население, которое как не ищет, так и не планирует свое участие на рынке труда, из которых примерно 45\% составляют пенсионеры и 14,5\% учащиеся, студенты, а остальная часть остается практически за пределами рынка труда. Ситуация в регионах неоднозначна, многое зависит от демографической ситуации (естественный прирост, соотношение численности городского и сельского населения, возрастно-половая структура, миграция) и развития социально-экономической инфраструктуры и, как результат, основные показатели рынка труда имеют различные характеристики как по уровню экономической активности, так по уровню занятости. Наиболее высокие показатели экономической активности и занятости в мун.Кишинэу, в котором сосредоточен основной потенциал хозяйствующих субъектов и, соответственно, возможности для трудоустройства, повышения профессионального мастерства, карьерного роста, доходов (Таблица 3). 
Таблица 3. Динамика основных показателей рынка труда, \%

\begin{tabular}{|l|c|c|c|c|c|}
\hline & $\mathbf{2 0 1 6}$ & $\mathbf{2 0 1 7}$ & $\mathbf{2 0 1 8}$ & $\mathbf{2 0 1 9}$ & $\mathbf{2 0 2 0}$ \\
\hline Уровень экономической активности по РМ & 44,8 & 44,1 & 45,9 & 42,3 & 40,3 \\
\hline Мун.Кишинэу & 50,2 & 49,0 & 49,8 & 55,1 & 51,2 \\
\hline Север & 47,2 & 47,1 & 48,3 & 44,4 & 43,0 \\
\hline Центр & 43,0 & 41,6 & 45,1 & 35,9 & 34,8 \\
\hline Юг & 36,9 & 37,3 & 38,4 & 33,2 & 31,4 \\
\hline Уровень занятости в целом по РМ & 43,0 & 42,4 & 44,5 & 40,1 & 38,8 \\
\hline Мун.Кишинэу & 47,3 & 46,2 & 47,3 & 52,6 & 48,8 \\
\hline Север & 45,5 & 45,6 & 46,8 & 42,5 & 41,3 \\
\hline Центр & 41,3 & 40,1 & 44,5 & 33,6 & 33,8 \\
\hline Юг & 36,2 & 36,3 & 37,6 & 31,3 & 30,3 \\
\hline Уровень безработицы МБТ в целом по РМ & 4,0 & 3,9 & 2,9 & 5,1 & 3,8 \\
\hline Мун.Кишинэу & 5,7 & 5,8 & 5,0 & 4,6 & 4,6 \\
\hline Север & 3,7 & 3,0 & 3,1 & 4,3 & 4,0 \\
\hline Центр & 4,0 & 3,7 & 1,4 & 6,3 & 2,9 \\
\hline Юг & 1,8 & 2,7 & 2,0 & 5,8 & 3,5 \\
\hline Официально зарегистрированные & & & & & \\
безработные НАЗН, человек - всего & 26889 & 22386 & 18696 & 16598 & 50226 \\
в \% от общего количества: & & & & & \\
\hline Мун.Кишинэу & 5,7 & 5,2 & 4,2 & 3,7 & $\ldots$ \\
\hline Север & 46,8 & 46,0 & 47,2 & 50,3 & $\ldots$ \\
\hline Центр & 30,0 & 33,1 & 33,0 & 28,2 & $\ldots$ \\
\hline Юг & 14,0 & 11,8 & 11,2 & 12,8 & $\ldots$ \\
\hline АТО Гагаузия & 3,5 & 3,9 & 4,4 & 5,0 & $\ldots$ \\
\hline
\end{tabular}

Источник: Согласно данным НБС РМ,

https://statbank.statistica.md/pxweb/pxweb/ro/60\%20Statistica\%20regionala/60\%20Sta tistica\%20regionala_03\%20FM/?rxid=9a62a0d7-86c4-45da-b7e4-fecc26003802, Anuarul statistic al Republicii Moldova, BNS,

https://statistica.gov.md/pageview.php?l=ro\&idc=350\&nod=1\&

В 2020г. среднереспубликанские показатели экономической активности (на 2,7 п.п.) и занятости (на 2,5 п.п.) превышены в Северной зоне, в том числе мун.Бэлць, что объясняется наличием промышленных предприятий, социальной инфраструктуры, транспортной сети. В Центральной и Южной зонах показатели экономической активности и занятости населения ниже, чем в среднем по стране (в 2019-2020г.г. на 6,4п.п. и 5,0 п.п. в Центральной и на 9,1 п.п. и на 8,9 п.п в Южной зоне), а уровень занятости населения был ниже среднереспубликанского на 6,5п.п. и 5,5 п.п. в Центральной и на 8,8 п.п. и на 8,5 п.п в Южной зоне (Таблица 4). 
Таблица 4. Характеристика уровня доходов и социальных стандартов по региональном аспекте Республики Молдова

\begin{tabular}{|c|c|c|c|c|c|}
\hline & 2016 & 2017 & 2018 & 2019 & 2020 \\
\hline $\begin{array}{l}\text { Среднемесячная заработная плата на } \\
\text { одного работающего по РМ, лей }\end{array}$ & 4997,8 & 5587,4 & 6268,0 & 7233,7 & 7943,0 \\
\hline Мун.Кишинэу & 5951,5 & 6716,4 & 7490,0 & 8686,4 & 9561,3 \\
\hline Север & 4211,9 & 4665,2 & 5259,5 & 5916,1 & 6501,2 \\
\hline Центр & 4061,8 & 4522,3 & 5084,0 & 5910,6 & 6429,9 \\
\hline Юг & 3881,6 & 4257,0 & 4814,7 & 5572,2 & 6151,3 \\
\hline АТО Гагаузия & 3867,1 & 4268,2 & 4799,5 & 5554,9 & 6150,7 \\
\hline \multicolumn{6}{|c|}{ Отношение среднемесячной заработной платы в \% к средней по PM (PM=100,0) } \\
\hline Мун.Кишинэу & 119,1 & 120,2 & 119,5 & 120,1 & 120,4 \\
\hline Север & 84,3 & 83,5 & 83,9 & 81,8 & 81,8 \\
\hline Центр & 81,3 & 80,9 & 81,1 & 81,7 & 80,9 \\
\hline Юг & 77,7 & 76,2 & 76,8 & 77,0 & 77,4 \\
\hline АТО Гагаузия & 77,4 & 76,4 & 76,6 & 76,8 & 77,4 \\
\hline \multicolumn{6}{|c|}{ Соотношение заработной платы женщин и мужчин, в \% } \\
\hline Мун.Кишинэу & 14,5 & 13,5 & 14,4 & 14,1 & 14,5 \\
\hline Север & 15,8 & 14,7 & 15,4 & 16,4 & 15,8 \\
\hline Центр & 9,1 & 11,3 & 11,2 & 7,9 & 9,1 \\
\hline Юг & 7,3 & 6,2 & 7,8 & 6,2 & 7,3 \\
\hline АТО Гагаузия & 7,8 & 6,1 & 7,3 & 4,9 & 7,8 \\
\hline $\begin{array}{l}\text { Располагаемый среднемесячный доход } \\
\text { на одного человека, лей* }\end{array}$ & 2051,8 & 2208,5 & 2357,1 & 2880,6 & 3096,6 \\
\hline Мун.Кишинэу & 2842,1 & 3049,4 & 3264,2 & 4184,5 & 4355,0 \\
\hline Север & 1830,7 & 1999,5 & 2131,3 & 2507,9 & 2729,7 \\
\hline Центр & 1785,8 & 1901,9 & 2082,7 & 2530,4 & 2811,2 \\
\hline Юг & 1802,2 & 1943,6 & 1985,6 & 2356,4 & 2524,5 \\
\hline $\begin{array}{l}\text { Прожиточный минимум трудоспособного } \\
\text { населения, лей на } 1 \text { человека }\end{array}$ & 1914,7 & 1984,5 & 2016,1 & 2194,0 & 2247,6 \\
\hline Порог абсолютной бедности, лей & 1819,2 & 1939,3 & 1998,4 & 2095,1 & ... \\
\hline Уровень абсолютной бедности, \% & 26,4 & 27,7 & 23 & 25,2 & 26,8 \\
\hline Мун.Кишинэу & 6,5 & 7,5 & 4,7 & 4,4 & 7,6 \\
\hline Север & 30,5 & 31,1 & 28,4 & 27,7 & 28,1 \\
\hline Центр & 35,7 & 36,6 & 28,7 & 29,8 & 30,6 \\
\hline Юг & 30,8 & 33,8 & 28,8 & 40,4 & 42,9 \\
\hline Порог экстремальной бедности, лей & 1467,2 & 1564 & 1611,7 & 1689,7 & $\ldots$ \\
\hline Уровень экстремальной бедности, \% & 10,4 & 11 & 8,7 & 10,7 & 10,8 \\
\hline Мун.Кишинэу & 2,0 & 1,4 & 1,1 & 1,4 & 2,9 \\
\hline Север & 13,3 & 10,7 & 10,5 & 10,4 & 11,1 \\
\hline Центр & 13,6 & 17,1 & 11,2 & 12,9 & 12,0 \\
\hline Юг & 11,8 & 13,8 & 11,6 & 19,2 & 18,5 \\
\hline Индекс потребительских цен & 106,36 & 106,57 & 103,05 & 104,84 & 103,77 \\
\hline продовольственные товары & 107,35 & 107,93 & 105,39 & 107,61 & 107,35 \\
\hline непродовольственные товары & 106,32 & 104,53 & 102,67 & 104,19 & 100,89 \\
\hline услуги & 104,90 & 107,06 & 99,78 & 101,47 & 102,38 \\
\hline
\end{tabular}

* Примечание: Начиная с 2019г. данные несравнимы с предыдущим периодом в связи с изменением методологии обследования бюджетов домашних хозяйств.

Источник: НБС РМ, www.statistica.md 
Важным социальным показателем является уровень безработицы. Так, несмотря на возможность быть занятым в мун.Кишинэу уровень безработицы выше, чем в среднем по стране практически на протяжении всего периода (за исключением 2019г.), в Центральной и Южной зонах в 2016-2018г.г. и 2020г.данный показатель ниже среднереспубликанского. Такая ситуация может быть связана не только с возможностью трудоустройства, но и с условиями труда и его оплатой, возможностью обеспечить достойный уровень жизни своей семье, обучение детей, доступ и получение качественных медицинских услуг.

Наиболее высокий уровень доходов в мун.Кишинэу, в 2020г. среднемесячная заработная плата превысила ее средний размер по стране в 1,2 раза и располагаемый среднемесячный доход в 1,4 раза, что, соответственно, больше размера прожиточного минимума трудоспособного населения в 4,2 раза по заработной плате и в 1,4 раза по располагаемому доходу. Как результат, в муниципии Кишинэу самый низкий уровень абсолютной и экстремальной бедности (в 2020г. соответственно, 7,6\% и 2,9\%), несмотря на то, что бедность еще имеет место при наличии как достаточно высоких доходов по сравнению с другими территориями, а также принимаемыми мерами социальной помощи со стороны государства и примэрии. Наиболее низкие доходы зарегистрированы в АТО Гагаузия (заработная плата ниже, чем по стране на $22,6 \%$ и на $35,7 \%$, чем в мун.Кишинэу) и в Южной зоне, в которой зарегистрирован самый высокий уровень абсолютной (на 16,1 п.п. чем в среднем по стране) и экстремальной (на 7,7 п.п. выше чем в среднем по стране) бедности населения. Ситуация, когда трудовой доход не является стимулирующей функцией, перестает играть свою функцию воспроизводства рабочей силы на рынке труда, феномен бедности трудоспособного населения - все эти факторы являются причиной мобильности рабочей силы, поиска работы за пределами территории проживания или страны, увеличивая потоки трудовой миграции.

Таблица 5. Динамика трудовой миграции, тыс.человек / \%

\begin{tabular}{|l|c|c|c|c|c|}
\hline & 2016 & 2017 & 2018 & $2019 *$ & $2020^{*}$ \\
\hline $\begin{array}{l}\text { Трудовые мигранты РМ, } \\
\text { всего, тыс.чел. }\end{array}$ & $\mathbf{1 2 8 , 8}$ & $\mathbf{1 4 0 , 6}$ & $\mathbf{1 4 7 , 4}$ & $\mathbf{1 0 5 , 9}$ & $\mathbf{9 0 , 4}$ \\
\hline Мун. Кишинэу & 10,2 & 13,5 & 14,3 & 9,1 & 11,8 \\
\hline Север & 33,1 & 29,1 & 32,6 & 24,2 & 21,7 \\
\hline Центр & 44,5 & 58,2 & 59,4 & 43,8 & 35,4 \\
\hline Юг & 41,1 & 39,9 & 41,2 & 28,7 & 21,5 \\
\hline \multicolumn{5}{|}{ Доля трудовых мигрантов в регионе в \% к общему их количеству по стране } \\
\hline Республика Молдова, всего & $\mathbf{1 0 0 , 0}$ & $\mathbf{1 0 0 , 0}$ & $\mathbf{1 0 0 , 0}$ & $\mathbf{1 0 0 , 0}$ & $\mathbf{1 0 0 , 0}$ \\
\hline Мун. Кишинэу & 7,9 & 9,6 & 9,7 & 8,6 & 13,1 \\
\hline Север & 25,7 & 20,7 & 22,1 & 22,9 & 24,0 \\
\hline Центр & 34,5 & 41,4 & 40,3 & 41,4 & 39,2 \\
\hline
\end{tabular}




\begin{tabular}{|l|c|c|c|c|c|}
\hline Юг & 31,9 & 28,4 & 28,0 & 27,1 & 23,8 \\
\hline Доля трудовых мигрантов в численности экономически неактивного населения, в \% \\
\hline Республика Молдова, всего & $\mathbf{1 0 , 1}$ & $\mathbf{1 1 , 1}$ & $\mathbf{1 2 , 3}$ & $\mathbf{8 , 4}$ & $\mathbf{7 , 0}$ \\
\hline Мун. Кишинэу & 3,7 & 4,9 & 5,5 & 4,0 & 4,8 \\
\hline Север & 9,7 & 8,7 & 10,1 & 7,1 & 6,3 \\
\hline Центр & 11,5 & 14,9 & 16,6 & 10,5 & 8,5 \\
\hline Юг & 15,1 & 15,0 & 16,1 & 10,5 & 7,8 \\
\hline
\end{tabular}

* 2019-2020, обследование рабочей силы в домашних хозяйствах (Анкета рабочей силы) проведено НБС РМ согласно нового плана и определения занятая рабочая сила.

Источник: Расчеты авторов на основе данных НБС РМ,

https://statbank.statistica.md/pxweb/pxweb/ro/30\%20Statistica\%20sociala/30\%20Statis tica\%20sociala_03\%20FM_03\%20MUN2019_MUN080/?rxid=b2ff27d7-0b96-43c9-934b42e1a2a9a774

Низкий уровень занятости и доходов, бедность - основные причины трудовой миграции в Центральной зоне (доля мигрантов в их общей численности в 2016-2018г.г. составляла от $34 \%$ до 41\%) и остается наибольшей в 2019-2020г.г -41,4\% и 39,2\%, несмотря на пандемический кризис и уменьшение их численности в абсолютном выражении, в том числе 85,6\% из сельской местности, а по возрастным группам превалируют группы 25-54 года (74\%) и 15-24года (20\%). В данной зоне фактор риска экономической безопасности очевиден, в ней высокая доля экономически неактивного населения, которое и не занимается поисками, и не готово приступить к работе (32\% из данной категории, в которой около 49\% составляют пенсионеры, Таблица 2). Несколько изменились тенденции: на фоне сокращения потоков трудовых мигрантов в Северной и Южной зонах, проявилась тенденция роста трудовых мигрантов в мун.Кишинэу, в том числе в 2019-2020г.г. численность их возросла только за один год на 29,8\%. По статистическим данным НБС за 2020г. $89 \%$ из них выехало из городской местности, 72\% из них мужчины, 69,5\% в возрастной группе 25-54 года и 23\% в возрасте 15-24 года. Миграция вызывает дисбаланс спроса и предложения, дестабилизацию, изменение возрастнополовой структуры рынка труда (Таблица 6). 
Таблица 6. Структура занятого населения по возрастным группам на национальном и локальных рынках труда

\begin{tabular}{|c|c|c|c|c|c|c|c|c|}
\hline & & 2016 & 2017 & 2018 & 2019 & 2020 & $\begin{array}{c}2018 \text { г. } \\
\text { к } \\
2014 \text { г.* } \\
\text { \% / } \\
\text { п.п. }\end{array}$ & $\begin{array}{l}\text { 2020г.к } \\
\text { 2019г.* } \\
\text { \% / п.п. }\end{array}$ \\
\hline \multicolumn{2}{|c|}{$\begin{array}{l}\text { Всего по Республике } \\
\text { Молдова, тыс.чел. }\end{array}$} & 993,7 & 960,8 & 988,5 & 872,4 & 834,2 & 100,7 & 95,6 \\
\hline \multirow{3}{*}{$\begin{array}{l}\text { Доля } \\
\text { возрастной } \\
\text { группы в } \\
\text { общей } \\
\text { численности } \\
\text { занятых, \% }\end{array}$} & $15-24$ лет, $\%$ & 7,0 & 6,6 & 6,8 & 6,4 & 5,5 & $-0,2$ & $-0,9$ \\
\hline & $25-54$ лет, \% & 70,9 & 69,9 & 67,6 & 72,2 & 72,8 & $-3,3$ & 0,6 \\
\hline & $\begin{array}{l}55 \text { лет и } \\
\text { более }\end{array}$ & 22,1 & 23,5 & 25,6 & 21,4 & 21,7 & 3,5 & 0,3 \\
\hline \multicolumn{2}{|c|}{ Мун.Кишинэу, тыс.чел. } & 262,9 & 251,5 & 247,1 & 266,8 & 246,6 & 88,4 & 92,5 \\
\hline \multirow{3}{*}{$\begin{array}{l}\text { Доля } \\
\text { возрастной } \\
\text { группы в } \\
\text { общей } \\
\text { численности } \\
\text { занятых, \% } \\
\end{array}$} & 15-24 лет,\% & 7,2 & 6,8 & 8,4 & 8,1 & 7,0 & 1,2 & $-0,9$ \\
\hline & $25-54$ лет, \% & 75,4 & 75,6 & 75,4 & 77,0 & 77,0 & 0,0 & 0,0 \\
\hline & $\begin{array}{l}55 \text { лет и } \\
\text { более }\end{array}$ & 17,4 & 17,6 & 16,2 & 14,9 & 16,0 & $-1,2$ & 1,1 \\
\hline \multicolumn{2}{|c|}{ Север, тыс.чел. } & 292,5 & 287,3 & 290,9 & 260,1 & 251,1 & 106,1 & 96,5 \\
\hline \multirow{3}{*}{$\begin{array}{l}\text { Доля } \\
\text { возрастной } \\
\text { группы в } \\
\text { общей } \\
\text { численности } \\
\text { занятых, \% }\end{array}$} & 15-24 лет,\% & 7,5 & 7,5 & 6,7 & 6,4 & 5,0 & $-0,8$ & $-1,4$ \\
\hline & $25-54$ лет, \% & 68,4 & 66,9 & 64,9 & 67,4 & 69,1 & $-3,5$ & 1,7 \\
\hline & $\begin{array}{l}55 \text { лет и } \\
\text { более }\end{array}$ & 24,1 & 25,6 & 28,4 & 26,2 & 25,9 & 4,3 & $-0,3$ \\
\hline \multicolumn{2}{|c|}{ Центр, тыс.чел. } & 281,5 & 268,4 & 294,7 & 217,7 & 215,3 & 108,9 & 98,9 \\
\hline \multirow{3}{*}{$\begin{array}{l}\text { Доля } \\
\text { возрастной } \\
\text { группы в } \\
\text { общей } \\
\text { численности } \\
\text { занятых, \% } \\
\end{array}$} & 15-24 лет,\% & 7,1 & 6,3 & 6,0 & 5,5 & 5,0 & $-1,1$ & $-0,5$ \\
\hline & 25-54 лет, \% & 69,6 & 68,6 & 65,8 & 71,4 & 72,0 & $-3,8$ & 0,6 \\
\hline & $\begin{array}{l}55 \text { лет и } \\
\text { более }\end{array}$ & 23,3 & 25,1 & 28,2 & 23,1 & 23,0 & 4,9 & $-0,1$ \\
\hline \multicolumn{2}{|l|}{ Юг, тыс.чел. } & 156,8 & 153,6 & 155,8 & 127,8 & 121,2 & 99,2 & 94,8 \\
\hline \multirow{3}{*}{$\begin{array}{l}\text { Доля } \\
\text { возрастной } \\
\text { группы в } \\
\text { общей } \\
\text { численности } \\
\text { занятых, \% }\end{array}$} & 15-24 лет,\% & 5,5 & 5,3 & 5,6 & 4,6 & 4,2 & 0,1 & $-0,4$ \\
\hline & $25-54$ лет, \% & 70,2 & 67,6 & 63,5 & 73,2 & 73,3 & $-6,7$ & 0,1 \\
\hline & $\begin{array}{l}55 \text { лет и } \\
\text { более }\end{array}$ & 24,3 & 27,1 & 30,9 & 22,2 & 22,5 & 6,6 & 0,3 \\
\hline
\end{tabular}

*Примечание: изменение абсолютных данных приведено в процентах, а доли - в процентных пунктах.

Источник: Разработано авторами на базе статистических данных НБС РМ и собственных расчетов, www.statistica.md

Из анализа занятого населения очевидна тенденция его убыли как на национальном рынке труда, так и на рынках мун, Кишинэу (за 2014- 
2018г.г. на 11,6 п.п. и только за один год 2019-2020г.г. на 7,5 п.п.) и в Южной зоне (за 2014-2018г.г. на 0,8 п.п. и только за один год 20192020г.г. на 5,2 п.п.), а в 2020г. по сравнению с 2019г. сокращение численности занятых на 4,4 п.п. произошло за счет их уменьшения по всем локальным рынкам труда. При этом данное уменьшение происходит за счет постепенного сокращения доли молодежной группы 15-24 лет (в 2014-2019 годах на 0,2 п.п. и 2019-2020гг. на 0,9 п.п.), а также и наиболее продуктивной возрастной группы 25-54 года и особенно, за 2014-2018гг. (на 3,3 п.п. по РМ; на 6,7 п.п. на Юге; на 3,8 п.п. а Центре и 3,5 п.п. на Севере) и при росте возрастной группы 55 лет и более (на Юге на 6,6 п.п.; в Центре на 4,9 п.п.; на Севере на 4,3 п.п.). Несмотря на изменения в структуре занятого населения, в 2020г. основной возрастной группой на рынке труда остается рабочая сила в возрасте 25-54 года, доля которой варьирует в интервале в основном 72\%-77 \%, доля молодежи падает до 5\% (в мун,Кишинэу $-7,0 \%$ ) и возрастает доля возрастной группы 55 лет и более (22\% и более), то есть идет процесс старения рынка рабочей силы, что является определенным риском экономической безопасности и выдвигает на первый план проблемы как повышения продуктивной занятости старшей возрастной группы, так и создания будущего резерва рабочей силы для обеспечения нужд стабильного экономического развития страны и конкурентоспособности рынка труда. Так, 2019г.-2020г., в условиях кризиса пандемии Covid-19 имели место сокращения или прекращение отдельных видов экономической деятельности, сокращение спроса на рабочую силу, уменьшение предлагаемых свободных (вакантных) рабочих мест (в 2019г. по сравнению с 2018г. на 30,1\% и в 2020г. по сравнению с 2019г. - на 29,7\%). При этом введение режима «дистанционной работы» вызвало необходимость знаний компьютерной техники, применения IT и других, которыми не всегда владела рабочая сила в старших возрастах, что отразилось на возможности продолжения трудовой деятельности и на трудоустройстве безработных, особенно, в 2020г., когда резко возросла напряженность на рынке труда. В возрастной структуре пострадавших от пандемии доля группы 25-34 года варьирует в пределах от $24 \%$ до $36 \%$ или в среднем за год на $26,4 \%$, группы $35-44$ года - в интервале $14-$ $28 \%$ или в среднем за год 25,9\% и группы $45-54$ года в $18-23 \%$ или в среднем $22,4 \%$, и возрастной группы 55-64 года в среднем за год 22,4\%, а в наименьшей степени пострадала возрастная группа 15-24 года или в среднем за год это составляет на 5,4\% (НБС, 2021). В 2020г. на фоне кризиса пандемии, по данным НАЗН, сократилось количество свободных рабочих мест при росте безработных в 1,6 раза, доля безработных в возрастной группе 16-35 лет составила $33,6 \%$ и в возрасте 55-63 года 18,1\% (Таблица 7). 
Таблица 7. Основные показатели мобильности на рынке труда

\begin{tabular}{|l|c|c|c|c|c|}
\hline & $\mathbf{2 0 1 6}$ & $\mathbf{2 0 1 7}$ & $\mathbf{2 0 1 8}$ & $\mathbf{2 0 1 9}$ & $\mathbf{2 0 2 0}$ \\
\hline $\begin{array}{l}\text { Количество вакантных рабочих } \\
\text { мест зарегистрированных в НАЗН, } \\
\text { тыс. мест }\end{array}$ & 44,6 & 45,4 & 49,2 & 34,3 & 24,1 \\
\hline $\begin{array}{l}\text { Численность зарегистрированных } \\
\text { безработных в НАЗН в течении } \\
\text { года, тыс.чел. }\end{array}$ & 50,0 & 42,1 & 35,5 & 31,5 & 50,2 \\
\hline $\begin{array}{l}\text { Численность зарегистрированных } \\
\text { НАЗН безработных на конец года, } \\
\text { тыс.чел }\end{array}$ & 26,9 & 22,4 & 18,7 & 16,6 & 25,5 \\
\hline $\begin{array}{l}\text { в том числе в \% к предыдущему } \\
\text { году }\end{array}$ & 99,9 & 83,3 & 83,5 & 88,8 & 153,8 \\
\hline $\begin{array}{l}\text { Коэффициент напряжённости, } \\
\text { единиц }\end{array}$ & 1,12 & 0,93 & 0,72 & 0,92 & 2,08 \\
\hline $\begin{array}{l}\text { Доля трудоустроенных НАЗН } \\
\text { безработных, \% от общего их } \\
\text { количества }\end{array}$ & 35,3 & 39,5 & 41,4 & 35,7 & 18,2 \\
\hline $\begin{array}{l}\text { Соотношение количества } \\
\text { принятых наемных работников к } \\
\text { уволенным, единищ* }\end{array}$ & 0,97 & 1,02 & 1,07 & 0,99 & 0,96 \\
\hline $\begin{array}{l}\text { Количество принятых в \% от } \\
\text { количества рабочих мест* }\end{array}$ & 22,7 & 24,0 & 28,6 & 26,3 & 23,0 \\
\hline $\begin{array}{l}\text { Количество уволенных в \% от } \\
\text { количества рабочих мест * }\end{array}$ & 23,4 & 24,4 & 26,7 & 26,6 & 24,0 \\
\hline $\begin{array}{l}\text { Количество созданных новых } \\
\text { рабочих мест, единиц* }\end{array}$ & 50058 & 57671 & 76547 & 58551 & 54916 \\
\hline $\begin{array}{l}\text { Количество ликвидированных } \\
\text { рабочих мест, единиц* }\end{array}$ & 58458 & 55402 & 63165 & 58104 & 64102 \\
\hline $\begin{array}{l}\text { Количество вакантных рабочих } \\
\text { мест на конец года, единиц* }\end{array}$ & 31336 & 33101 & 37588 & 42190 & 37571 \\
\hline $\begin{array}{l}\text { Количество вакантных рабочих } \\
\text { мест в \% к общему количеству на } \\
\text { конец года }\end{array}$ & 4,3 & 4,5 & 4,7 & 5,2 & 4,7 \\
\hline
\end{tabular}

*Примечание: данные НБС РМ, вакансиями считаются должности, предназначенные для лиц как за пределами, так и внутри подразделения, независимо от того, являются ли они фиксированными или на неопределенный срок, с обычным или частичным графиком работы,

https://statbank.statistica.md/pxweb/pxweb/ro/30\%20Statistica\%20sociala/30\%20Statis tica\%20sociala_03\%20FM_03\%20MUN2019_MUN010/?rxid=2345d98a-890b-4459bb1f-9b565f99b3b9

Источник: Разработана авторами на основе данных НАЗН и собственных расчётов, www.anofm.md; НБC PM

Оценка мобильности рабочей силы и рабочих мест показывает резкое снижение в 2019-2020 годы количества вакансий (на 30,3\% в 2019г. по сравнению с 2018г. и на 29,7\% в 2020г. по сравнению с 2019г.), представленных экономическими агентами Национальному Агентству по Занятости Населения (НАЗН) для трудоустройства безработных, что 
явилось одним из факторов уменьшения шансов безработных получить работу, количество трудоустроенных безработных уменьшилось на 5,7 п.п. в 2019г. по сравнению с 2018г. и на 17,5 п.п. в 2020г. по сравнению с 2019г., коэффициент напряженности на рынке труда в 2020г. резко увеличился до 2,08 (более, чем в 2 раза). В то же время, обращаем внимание, что данные НАЗН и данные статистики о наличии свободных мест отличаются: если в НАЗН, например, в 2020гг. количество мест 24,1 тыс., то количество вакансий декларируемых в статистических отчетах работодателей 37,6 тыс.мест, то есть дополнительная возможность быть трудоустроенным и повысить уровень занятости населения имеется и речь может идти только о профессиональном соответствии требованиям работодателя, территориальном расположении или других условий работы. Следует обратить внимание на ротацию работников, соотношение между принятыми наемными работниками и уволенными, оно практически совпадает за исключение 2017г. и 2018г., когда число уволившихся превысило число вновь принятых. Следовательно, проблема занятости населения является вызовом для органов центрального и локального управления, занимающихся разработкой и внедрением политик в области занятости для обеспечения сбалансированности спроса и предложения рабочей силы на рынках труда, предотвращения рисков экономической безопасности и стабильного социально-экономического развития территорий и страны в целом.

Выводы. Анализ национального и региональных рынков труда, как фактора экономической безопасности, показал, что имеет место риск снижения потенциала трудовых ресурсов от влияния негативных тенденций уменьшения численности и старения населения. Трудовая миграция, мобильность рабочей силы и рабочих мест, низкая заработная плата в условиях инфляционных процессов, риск безработицы и бедности, особенно, занятого населения и кризис пандемии повлияли на стабильность и качество рынка труда и рост дефицита рабочей силы. В результате конъюнктурных изменений на локальных рынках труда произошло нарушение сбалансированности, повышение социальной напряженности и снижение конкурентоспособности национального рынка труда, что представляет угрозу экономической безопасности и вызовом для повышения государственных политик в области занятости населения и улучшения сложившей ситуации. В целях развития конкурентоспособного рынка труда, предотвращения возможных угроз экономической безопасности и устойчивого развития страны предлагаются следующие меры:

- Разработка и внедрение системы оценки экономической безопасности как на национальном, так и на уровне региона, в том числе критериев и основных целевых показателей возможных угроз; 
- мониторинг экономического развития регионов, характеристики возможных угроз и наличие потенциала для их преодоления или предотвращения, конкурентоспособности экономики региона;

- оценка сбалансированности рынка рабочей силы (баланс трудовых ресурсов, оценка конкурентоспособности рынка труда) по регионам и в целом по стране, в том числе с учетом демографических прогнозов населения, оценки потребности в профессиональных кадрах и наличия резерва рабочей силы;

- внедрение прогрессивных форм и систем оплаты труда, в том числе в реальном секторе экономики с учетом опыта стран ЕC;

- совершенствование законодательной базы в области трудовых отношений (Трудовой Кодекс Республики Молдова), в том числе с учетом дистанционной работы, изменения режима, условий работы и оценки результатов деятельности при чрезвычайных, нестандартных ситуациях занятости;

- совершенствование и развитие информационной платформы НАЗН в регионах для повышения уровня информированности населения о наличии вакантных рабочих мест, условиях занятости и оплате труда, новых современных профессиях на рынке труда, требованиях к вакантным должностям и наличии социальных пакетов;

- повышение уровня социальной защиты занятого населения, особенно, в случае риска безработицы и бедности с учетом стандартов и критериев MOT и опыта стран EC.

\section{ЛИТЕРАТУРА}

Cable, V. (1995). What is International Economic Security? International Affairs, Vol. 71, 2, 312-317.

Freeman, C. (1995). The National System of Innovation in Historical Perspective. Cambridge Journal of Economics, Vol.19, 1, 5-24.

Абалкин, Л. (1994). Экономическая безопасность России: угрозы и их отражение. Вопросы экономики, 12, 4-13.

Гладун, Т. (б.д.). Индикативный анализ показателей экономической безопасности Российской Федерации. https://cyberleninka.ru/article/n/indikativnyy-analiz-pokazateleyekonomicheskoy-bezopasnosti-rf/viewer.

Зайцева, Н. (2021). Рынок труда как составляющая экономической безопасности государства. Труды БГТУ, серия 6, 1, 112-115. https://elib.belstu.by/bitstream/123456789/41683/1/21.\%20\%d0\%97\%d 0\%b0\%d0\%b9\%d1\%86\%d0\%b5\%d0\%b2\%d0\%b0.pdf.

НБС РМ. (2021). Impactul Covid-19 asupra indicatorilor forței de muncă în anul 2020. www.statistica.md. 